\title{
Teenagers opinion regarding existing school furniture and musculo-skeletal problems
}

\author{
S.N. ADMANKAR* AND H.L. SARAMBEKAR \\ Department of Family Resource Management, College of Home Science, Vasantrao Naik Marathwada \\ Agricultural University, PARBHANI (M.S.) INDIA (Email : sarmhema@yahoo.co.in)
}

\begin{abstract}
Teenagers spend a large part of their school days in the classroom, and yet the effect of the design of school furniture on their behavior and health has received comparatively little attention. The desk height, desk depth, length of desk, chair depth, chair breadth for girls and combined group was noted to be less than required. Inclusive of these dimensions the backrest height and breadth was less than required by the boys resulting in uncomfortable feeling and pain due to use of furniture. The furniture used by teenagers was opined as comfortable and uncomfortable the results of these opinions are given in the Fig. 1 and 2 . It is clear from the figures that 47.3 and 50 per cent girls and boys felt that the desk height was comfortable while (52\% to $49 \%$ ) girls and boys said that they experienced uncomfortable due to desk height. The Table 1 depicts the frequency of musculo-skeletal problems faced by the teenagers. It is clear from the table that 62.7 per cent boys and 46.7 per cent girls never experienced fatigue. While the fatigue was rarely felt by 47 per cent girls and 34 per cent boys. Frequency of fatigue experienced sometimes was at par in girls and boys $(3.33 \%)$. Frequent fatigue was felt by of meager per cent of girls (2.2).
\end{abstract}

KEY WorDS : Teenagers, Opinion, Existing furniture, Frequency, Pain

View Point Article : Admankar, S.N. and Sarambekar, H.L. (2015). Teenagers opinion regarding existing school furniture and musculo-skeletal problems. Internat. J. Home Sci. Extn. \& Comm. Manage., 2 (1): 13-17.

Article History : Received : 30.07.2014; Revised : 19.11.2014; Accepted : 05.12 .2014

* Author for correspondence : Email : admankar.sandhya@ rediffmail.com 